\title{
Traces of Spiritual Nationalism in the Selected Poems of Ranu Uniyal and Arundhati Subramaniam
}

\author{
Dr. Neelam
}

Assistant Professor

Smt. B.D.Jain Girls PG College Agra Cantt

Agra, Uttar Pradesh, India

nneelam05@gmail.com

Abstract

RanuUniyal and Arundhati Subramaniam are contemporary Indian English Poets. They are deeply rooted in Indian soil. Their poems are full of Indian ethos and deal with a wide variety of subjects. Spiritual nationalism is one of them. Like Aurobindo Ghosh, for them nationalism means true devotion towards one's country and its people irrespective of their faith, caste, race and sex. India is a multilingual, multicultural and multireligious country. The conflicts on the basis of religion and culture are inevitable. People are often misguided by conservative and narrow- minded religious leaders and politicians which sometimes results in riots. Both Uniyal and Subramaniam believe that riots in a multicultural country like India are inescapable. India has faced so many invasions and incursions but continued to grow with the passage of time. The biggest strength of India is its spiritualism. It has empowered it during all external and internal assaults. Uniyal and Subramaniam believe that the negative forces which are destroying the peace and harmony of the nation can be defeated by realizing the core values of Indian culture. The objective of this research paper is to compare and explore the national ethos present in their selected poems: "In a City of Riots" by Uniyal and "Home" by Subramaniam 
Keywords: Nationalism, Culture, Spiritual Nationalism, Religion, Acceptance, Assimilation, Spirituality

The present paper focuses on the poems "In a City of Riots"by RanuUniyal and "Home" by Arundhati Subramaniam. The poems of both the poets are deeply rooted in Indian ethos. They believe in Indian mysticism and spirituality. They have used myths in their several poems not to glorify Indian culture but their relevance in the current. Their poetry is full of varied themes. Nationalistic zeal is one of them. The aim of this research paper is to compare and uncover the aspects of national ethos present in the poems: "In a City of Riots" by Uniyal and "Home" by Subramaniam.

The term "Nationalism" in itself is very intricate. It is difficult to give a proper definition of it. In common parlance it means devotion to one's nation. There is no single nationalism but nationalisms. And spiritual nationalism is one of them. This term was used by Sri Aurobindo Ghosh in his book Nationalism, Religion and Beyond: Writings on Politics, Society and Culture. For him nation is not an 'imagined community' but a 'mighty Shakti'. He says, "I look upon my country as mother"(NRB 28). Like him Pt. Jawahar Lal Nehru too believed: "the nation was the whole people, victory of nation means victory of the whole people, people like them and me"(qtd.in Chatterjee, NTCW 147). Aurobindo saw spirituality in the all aspect of life. For him true nationalism is full of spiritualism. To serve the country was a spiritual act because serving country means serving humans. Even "Gandhiji often expressed the view that the spirit of synthesis was the essential hallmark of Indian Civilization"(Tharoor 137). Such spirit of synthesis is explicit in the poems of Ranu Uniyal and Arundhati Subramaniam.

The poem "In a city of Riots" reflects RanuUniyal'swish for a place which is full of love and harmony as she writes: "will you draw for me/a neat house with as many/room as nights of love?(18) Subramaniam too dreams for “...a home/.../where I can slip in and out of 
rooms/without a trace/never worrying/ about the plumbing/the colour of curtains,/the cacophony of books by bedsides"(Nnw41). The lines show the multiculturalism of India. One can observe variations in the food, clothing and traditions of the Indian people. With so many variations it becomes hard to maintain harmony. Clashes and conflicts become inevitable. Sometimes these conflicts result in riots which destroy the peaceful atmosphere of the country. Both the poets cherish Hindu values. While talking about Hinduism as religion Shashi Tharoor believes that Hinduism is a faith without dogma. "it is a faith that allows each believer to stretch his or her imagination to a personal notion of the creative godhead of divinity'(9)...it was part of the agglomerative nature of Hinduism that it neither rejected nor dismissed the faiths it encountered, but sought to bring them into the fold"(18). Uniyal is of the view that in multicultural and religious society it becomes unavoidable to escape riots. As she writes: “...where will you go/when shutters are down after the weekend riots?"(18) She is very realistic while portraying the mindset of rioters and pseudo nationalism. She questions: "will you erase my belief/that the world is seeking/not a saint, but a rebel/to set itself free from/the scab of inequality?"(18-19)The riots in the name of religion often happens as people are instigated by their religious guru who portray themselves as the protector and preserver of the religion. These riots destroy the peaceful and tranquil atmosphere of the country. Indian politics is also dominated by religion and caste. When a country falls prey to such evils it is hard to move on the path of progress because it hinders logicality and rationality among people. Swami Vivekananda was not blind to the suffering Indians when he was preaching the Vedanta. He always felt that religion cannot be taught to an empty stomach. He startedRamkrishna Mission not only to spread teachings of Vedanta across India but to serve the suffering mass.He strongly adhered that "a man must have not only faith, but intellectual faith"(Tharoor 125).Uniyal too believes in the same doctrine. She wishes that people need to be logical as religion and rationality complement each other. Religion is meant to make 
people peaceful being. Every religion teaches to love each other. How and why people hate and kill each other for religion's sake, is the biggest question which is still unanswered?She pertinently asks: "will you scrub me clean /with mud from the Dead sea/ and the water from the Ganges...will you defy the scriptures/and devote a new tongue/with Om, Amen, and Allah/inscribed in it as signifiers/of one and the same light? (Uniyal 19) The lines show the poet's desire to have unity in diversity. She seeks that nationalism which is inclusive. She hates such nationalism which segregates people in the name of religion, race and community. While talking about nationalism, Anthony Smith says that the borrowing and adaptions of the developmental models with the aim of regenerating the national culture relates to some extent to assimilation and it should be encouraged. Flexibility is essential for existence.

Subramaniam visions a nation “where rooms aren’t clogged/with yesterday’s conversations/where the self does not bloat/to fill in the crevices"(Nnw 41). The poet believes the cause of clashes among different communities and people is their ego. Ego misguides man. Rejection of ego means acceptance of flexibility which broadens our cultural and spiritual sense. She craves for a space which gives her opportunity to develop her own individuality and sense of being. She is against fanaticism which kills one's individuality. That's why she desires "a home like this body/so alien when I try to belong/so hospitable/when I decide I'm just visiting”(Nnw 41).Assimilation and Acceptance are integral to Indian culture. Both Subramaniam and Uniyal uphold these ideas. Shashi Tharoor says: "if we can bring dharma into our national life, it must be to uphold, rather than at the expense of, our pluralist Indianness"(142).Gandhi has said, "who are conscious of the spirit of nationality do not interfere with one another's religion".(40) He has always reiterated that essentiality of Indian civilization is the spirit of synthesis. Uniyal reasserts this idea when she asks her people to devote a new tongue shading the derogatory ideas of 'otherness'. She wishes that all should come together and "sing of everlasting joy, sat chid Ananda."(Uniyal 
19) The lines show her spirit of one nation one goal i.e. happiness and prosperity for all irrespective of caste and creed.

Both the poets make us conscious of the territorial division which gives space to the segregation to penetrate among people. They insights us not to blame others for the mishaps taking place in the country. We need to look at ourselves, the weaknesses which are present in us. While talking on the topic of "Why was India lost", Gandhiji writes: "The English have not taken India; we have given it to them. They are not in India because of their strength, but because we keep them" (31). So, it is better to focus on our faults instead of blaming others. As an individual we need to think of our own action and thoughts. Subramaniam believes that a man has no single identity but multiple. And confinement to a single rigid identity allows no space for growth. In the same way Uniyal speaks for the plurality. The essence of spirituality is inclusiveness. India has always welcomed this plurality since immemorial times. Swami Vivekananda says: "like fire in a piece of flint, knowledge exists in the mind; suggestion is friction which brings it out" (28). What we need is to accept the difference of opinion as it is a kind of suggestion, suggestions of others, lead us to thinking which result in development of mind. For such development variations in thoughts, opinions and ideas is necessary.

Subramaniam uses pauses in her poems which are symbolic of space which is necessary for development and growth. What we need, it is to give space to others' ideas and opinions which will develop an atmosphere of strength and understanding. She talks like a Vedic philosopher who seeks for detachment. The last stanza of the poem shows the idea that attachment brings pain and suffering but detachment brings revelation. It means if we want to understand one another we need to shun rigidity. Dr. Radhakrishnan has said, "the union for the study of religious attempts not to obliterate differences but study the distinctive qualities of different religion, what they made of themselves by a process of interaction with 
others...spiritual fellowship is the meaning of history"(264). Ranu Uniyal herself believes that the poem "In a City of Riots" critique the pervasive ideology of the state which is the most destructive of all forces. It is important to acknowledge principles of love and justice in establishing true bonds of human relationship" (5). Like Radhakrishnan, she seeks for union of all community and sects as she demands a "new tongue" which will encapsulates the others tongues too. The idea of unity in diversity is overt when she asks for "signifiers of one and the same light" (5).

Uniyal and Subramaniam are aware of Indian scenario and their poems portray it in a sensible way. Both seek for spiritualism as they believe this the only path which will lead towards prosperity and growth not for individual but the country. RanuUniyal while talking about prevailing scenario of the nation is very explicit. She brings the pervasive forces under scrutiny which are responsible for such state of the country. Her language is lucid and very practical. There is clarity of thoughts and ideas. When we observe the poem of Arundhathi Subramaniam, it is ambiguous. It is more metaphoric and musical as compare to Uniyal's poem. The word "Home" is very connotative as it is symbolic of country, human body, security and sense of belongingness. Her poem focuses more on the sense of individuality. She urges to respect the individuality of others. When she says, "give me a home/ that isn't mine" shows her ambivalent and mysterious attitude. According to Subramaniam "poetry is something that seeps into you, colonises you and before you know it, transforms you. I don't want the mysteries of it to be decoded. I often forget that poetry is an indication of not just one truth- the strength of a poem is a many layered truth"(The Hindu).

In a nut shell, both Subramaniam and Uniyal affirm to respect the 'otherness' of other. Devotion towards nation means devotion towards its people because a nation or country cannot exist without people. The Essence of Indianness lies in its spirituality which teaches to respect the fellow beings. India is known in the world for spirituality. It has welcomed people 
from all corners of the world and provided refuge to the persecuted ones. They criticize those forces which are trying to destroy the unity and integrity of India in the name of religion, caste, ethnicity and race. They bring such negative elements under the scanner, and try to evoke the consciousness of the people who fall prey to such forces and in a jiffy forget the core values of their culture. The whole poem of Uniyal is in a Question form, which tries to awake its reader from their slumbers, and coerce to question themselves- what type of country they want for themselves and their posterity? Through the poem she shows us mirror and asks us to see our own reflection. Subramaniam's poem shows the repressed desire of a citizen who desires for a conducive environment for his growth, progress and development at mental, physical and spiritual level. Both the poems break the boundary of race, religion and sex. Though the titles of both the poems seems to contradict teach other but the essence is same. "In a City of Riots" Uniyal condemns the destructive forces, she depicts the city full of violence and bloodshed, and the poem "Home" is Subramaniam's urge for security, freedom and multicultural society. The message of both the poems is- upliftment of nation through spiritual awakening. 


\section{Works Cited}

Anderson, Benedict. Imagined Communities: Reflections on the origin and spread of Nationalism. Verso,1983.

Chatterjee, Partha. The Nationalist Thought and the Colonial World: A Derivative Discourse. Zed Books, 1986.

Dash, Manu ed. Ninety-nine words:A Collection of Contemporary English Poems.Panchabati Publications, 2006.

Gandhi, Mahatama. Hind Swaraj.Rajpal\&Sons, 2009.

Ghosh, Aurobindo. Nationalism, Religion and Beyond: Writings on Politics, Society and Culture.Ed.PeterHeehs.pernanet Black,2005.

Mahesh, Chitra. "Poetry has the power to move and elate: Arundhathi Subramaniam".The Hindu,https;//www.thehindu.com/entertainment/dance/poetry-has-the-power-tomove-arundhati-subramaniam/article30347367.ece.Accessed by1 Feb.2022

Radhakrishnan, S. Occcasional Speeeches and Writings. Publication Divisions, 1957.

Smith, Anthony D. Nationalism: Theory, Ideology, History. Polity Press,2013.

The Compelete Works of Swami Vivekananda. Advaita Asharna,1986 rpt.2012.

Tharror, Shashi. Why I AM A HINDU. Aleph Book Company, 2018.

Uniyal, Ranu. The Day We Went Strawberry Picking in Scarborough. Dhauli Books, 2018.

Uniyal, R. 2020. 'Beyond the bend”, in J Sarangi\& A Walker(eds) Indian-Australian exchanges throughcollaboratioms poetic inquiry, TEXT special issue Number60, TEXT: Journal of writingandwritingcourses 24,2 (October):http://www.textjournal.com.au/speciss/issue6 0/Uniyal.p 